\title{
DETERMINANTS OF DEVELOPMENT OF THIRD PARTY LIABILITY INSURANCE: SELECTED APPROACHES, EXPERIENCE AND TRENDS IN POLAND
}

\author{
Maria GASIŃSKA \\ Technical University of Warsaw, Faculty of Management, Poland \\ e-mail: m.gasinska@wz.pw.edu.pl
}

\begin{abstract}
The article constitutes an attempt at discussing the determinants of the development of third party liability insurance in historical perspective and on the basis of the observation of trends witnessed in this field nowadays. The identified factors are linked to the functioning of both the demand and the supply aspect of the third party liability insurance market, providing a valuable indicator for insurance practice. The past decade has witnessed steady, though slow, expansion of the third party liability insurance market in terms of the number of contracts concluded, the share of the contributions toward it in the total contribution value as well as the level of the gross contribution assigned. The article characterizes four groups of factors responsible for the third party liability insurance market expansion, namely: (a) determinants resulting from relations between the parties and subjects of the third party liability insurance relation against the complex nature and specific character of the third party liability function; (b) determinants linked to the dynamic development of the so called risk-generating techniques and technologies leading to growth in the development of the so-called damage potential threatening both participants in the production process (including the service provision process) as well as product users and service recipients; (c) determinants of socioeconomic character, in particular the level of legal and insurance awareness of potential damage perpetrators and injured parties as well as material standing of households and financial standing of economic entities; (d) determinants linked to legal regulations, in particular, the leading role of regulations separating the compensatory function of third party liability with respect to the penal function in shaping the scope and value of regulations tightening the scope and principles of third party liability in certain areas of economic turnover and introducing insurance compulsion.
\end{abstract}

Keywords: risk management of third party liability insurance, third party liability insurance, determinants of the third party liability insurance market.

JEL Codes: G22

\section{$1 \quad$ Introduction}

Third party liability insurance occupies a significant place among the insurance instruments of risk management in economic and public activity as well as in professional activity and private life. This exceptional position of third party liability insurance results first and foremost from its construction and function as an instrument guarding the financial interests of not only the insured (and thus potential damage perpetrators) but also the injured.

The Polish insurance market has recently been characterized by steady expansion of the share of third party liability insurance measured in terms of the collection of contributions in the total aggregate of the gross contributions of the second section.

Over the past ten years, it exceeded 3 percentage points (Table 1 and Fig. 1). Simultaneously, an increase in gross premium occurred due in general third liability insurance (Table 2 and Fig. 2).

Viewed against the total number of insurance contracts in Section II covering the remaining nonlife insurance and material insurance, the data for the number of policies in Group 13 insurance reveal spectacular progress in the market of third liability insurance (Table 3, Fig. 3 and 4). 
Table 1. Share of the gross contribution assigned due from Group 13 insurance (third party liability insurance) in the total of Section II gross contribution aggregate (the remaining nonlife insurance) in the years 2005-2015 (source: State Insurance Office Reports, Annual Reports, 2014, Financial Supervision Commission Annual Reports;

Annual Reports 2016; Financial Supervision Commission Reports; Quarterly bulletin. Insurance Market 4/2015)

\begin{tabular}{|c|c|c|c|c|c|c|c|c|c|c|c|}
\hline Year & 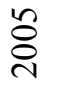 & ஓ̊ & $\hat{\overbrace{}}$ & $\stackrel{\infty}{\stackrel{\infty}{8}}$ & 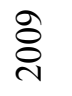 & $\stackrel{\circ}{\stackrel{0}{ }}$ & 공 & $\underset{ঠ}{\stackrel{ }{\delta}}$ & $\frac{n}{\delta}$ & $\frac{\Xi}{\stackrel{\nu}{\delta}}$ & $\frac{n}{\delta}$ \\
\hline $\begin{array}{l}\text { Share in real } \\
\text { terms in } \%\end{array}$ & 4.5 & 5.0 & 5.0 & 4.8 & 5.3 & 5.5 & 5.7 & 6.7 & 7.0 & 7.3 & 7.8 \\
\hline
\end{tabular}

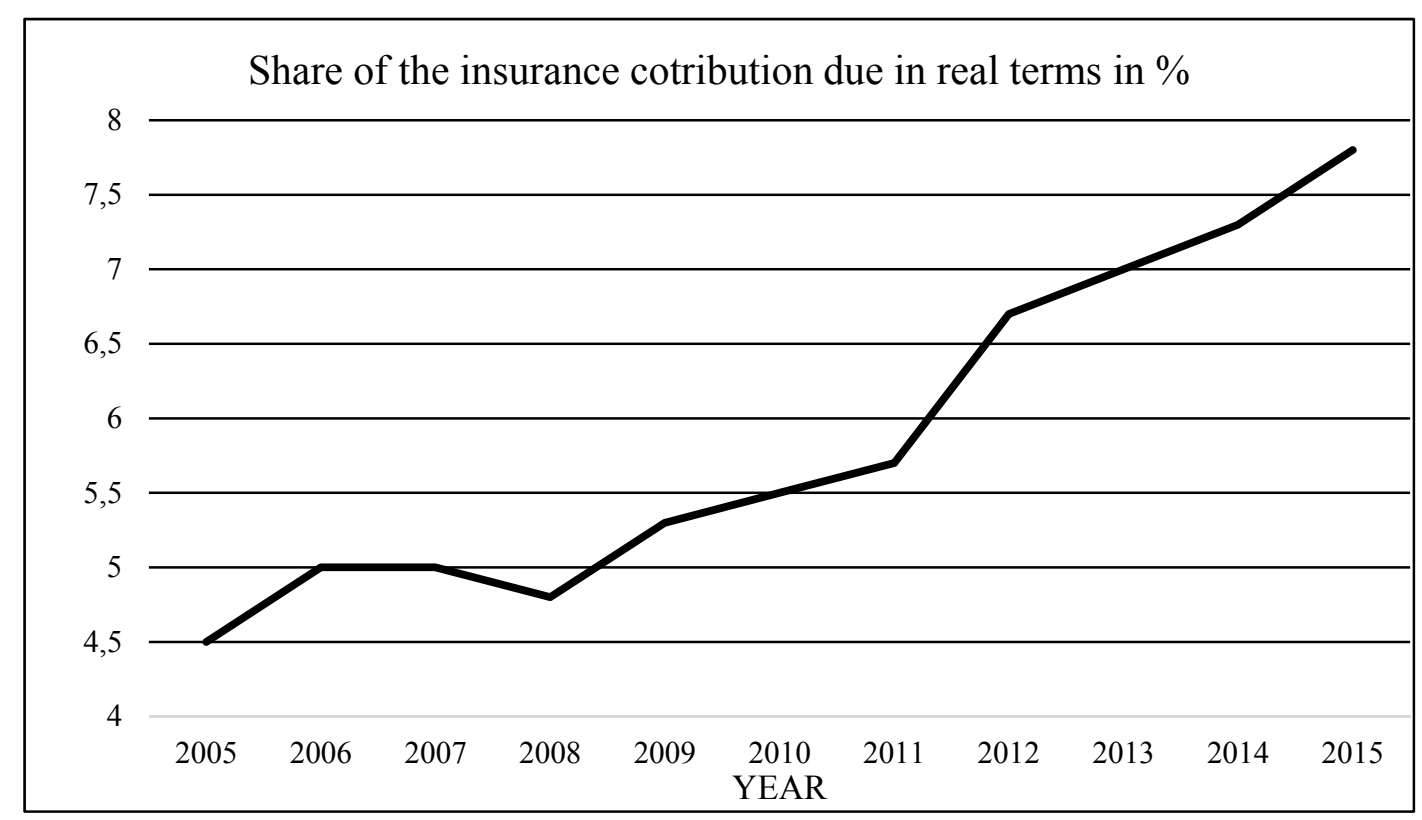

Figure 1. Change of the share of the gross contribution assigned due from Group 13 insurance (third party liability insurance) in the total aggregate of the Section II gross contribution (the remaining non-life insurance and pecuniary insurance in the years 2005-2015)

(source: own elaboration on the basis of: State Insurance Office Reports, Annual Reports 2014, Financial Supervision Commission Annual Reports; Annual Reports 2016; Financial Supervision Commission Reports; Quarterly bulletin. Insurance Market 4/2015)

Table 2. Gross insurance contribution due from Group 13 insurance (general third party liability insurance) (source: State Insurance Office Reports, Annual Reports 2014, Financial Supervision Commission Annual Reports; Annual Reports 2016; Financial Supervision Commission Reports; Quarterly bulletin. Insurance Market 4/2015)

\begin{tabular}{|c|c|c|c|c|c|c|c|c|c|c|c|c|c|}
\hline Year & 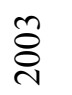 & ষ্ণ & ஜ̊ & ஓ̊ & 홍 & $\stackrel{\infty}{\stackrel{\Upsilon}{\circ}}$ & ஓి & $\stackrel{0}{\stackrel{0}{0}}$ & 롱 & $\stackrel{\sim}{\stackrel{\sim}{\circ}}$ & $\frac{n}{\circ}$ & $\stackrel{+}{\stackrel{\Upsilon}{0}}$ & $\frac{n}{8}$ \\
\hline $\begin{array}{l}\text { Contribution } \\
\text { in PLN m }\end{array}$ & 521 & 623 & 706 & 821 & 898 & 973 & 1113 & 1244 & 1440 & 1746 & 1858 & 1920 & 2012 \\
\hline
\end{tabular}




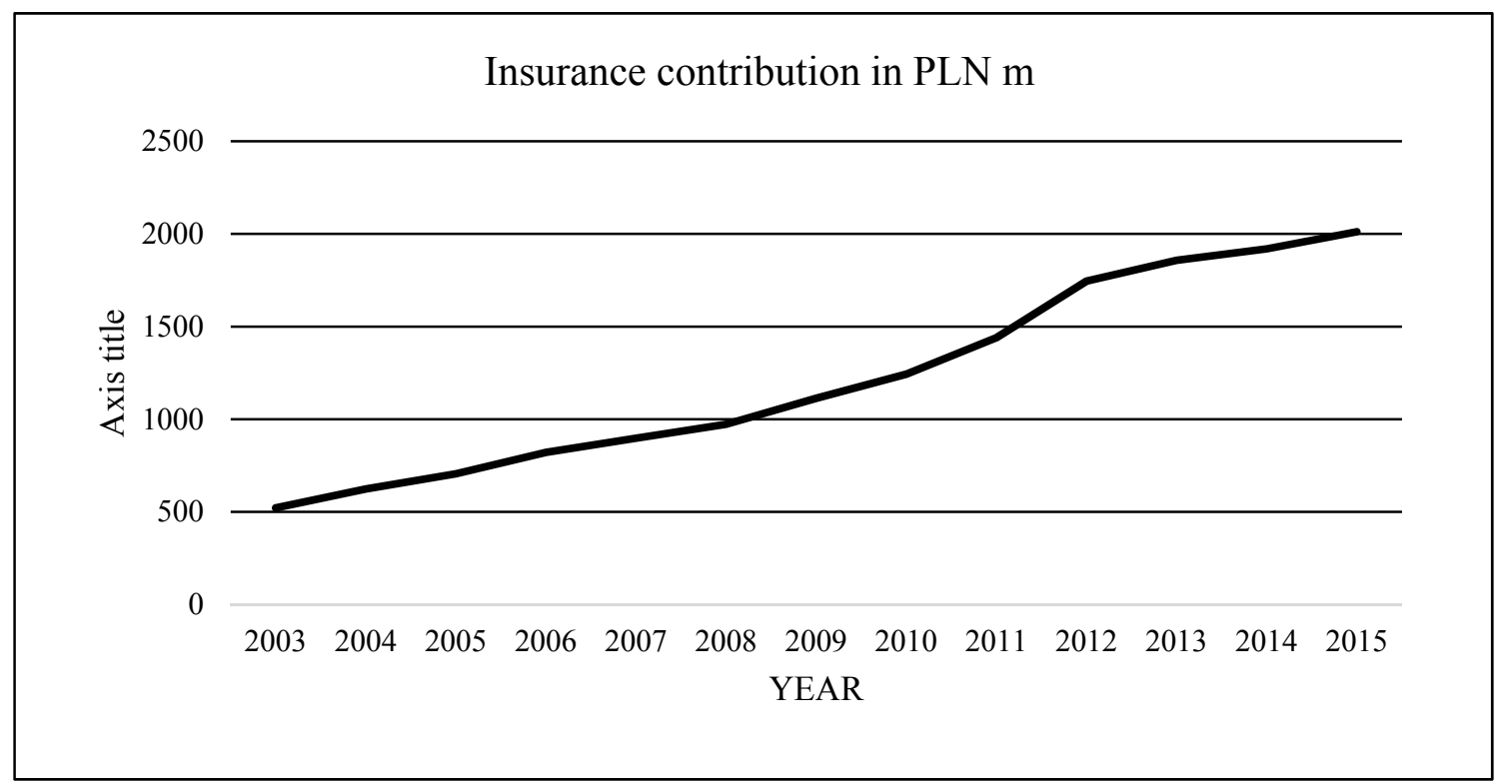

Figure 2. Gross insurance contribution due from Group 13 insurance (general third party liability insurance) (source: own elaboration on the basis of: State Insurance Office Reports, Annual Reports 2014, Financial Supervision Commission Annual Reports; Annual Reports 2016; Financial Supervision Commission Reports; Quarterly bulletin. Insurance Market 4/2015)

Table 3. General third party liability insurance contracts (Group 13) against the total number of insurance contracts in Section II in the years 2007-2015, in million pieces

(source: State Insurance Office Reports, Annual Reports 2014, Financial Supervision Commission Annual Reports; Annual Reports 2016; Financial Supervision Commission Reports; Quarterly bulletin. Insurance Market 4/2015)

\begin{tabular}{|c|c|c|c|c|c|c|c|c|c|}
\hline Year & $\hat{\stackrel{े}{े}}$ & $\stackrel{\infty}{\stackrel{i}{\sim}}$ & ठे & $\stackrel{\circ}{\circ}$ & $\overrightarrow{\check{i}}$ & 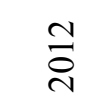 & $\stackrel{m}{\vec{i}}$ & $\stackrel{\Delta}{\stackrel{\sim}{\circ}}$ & $\stackrel{n}{\check{n}}$ \\
\hline $\begin{array}{l}\text { Number of policies } \\
\text { in Group } 13\end{array}$ & 3.78 & 4.91 & 5.84 & 6.35 & 6.62 & 6.73 & 6.90 & 8.78 & 9.71 \\
\hline $\begin{array}{l}\text { Total number of policies } \\
\text { in Section II }\end{array}$ & 58.09 & 60.24 & 46.87 & 49.76 & 49.20 & 47.18 & 47.78 & 55.07 & 51.41 \\
\hline $\begin{array}{l}\text { Share of policies in Group } 13 \\
\text { in the total number of policies } \\
\text { in Section II in \% }\end{array}$ & 6.50 & 8.15 & 12.46 & 12.76 & 13.46 & 14.26 & 14.44 & 15.94 & 18.88 \\
\hline
\end{tabular}

The years 2007-2015 witnessed an over twofold growth in the number of general third liability insurance contracts concluded (Fig. 3) against a decline in the number of insurance contracts concluded in Section II in the same period (particularly sharp in the years 2009-2013). Recovery in Section II took place in 2014 though the level of 2007 was not reached (the number of policies was ca. 3 million, i.e. over 5\% lower). The year 2005 saw another decline in the number of contracts in the area of nonlife insurance and material insurance (Fig. 4). 


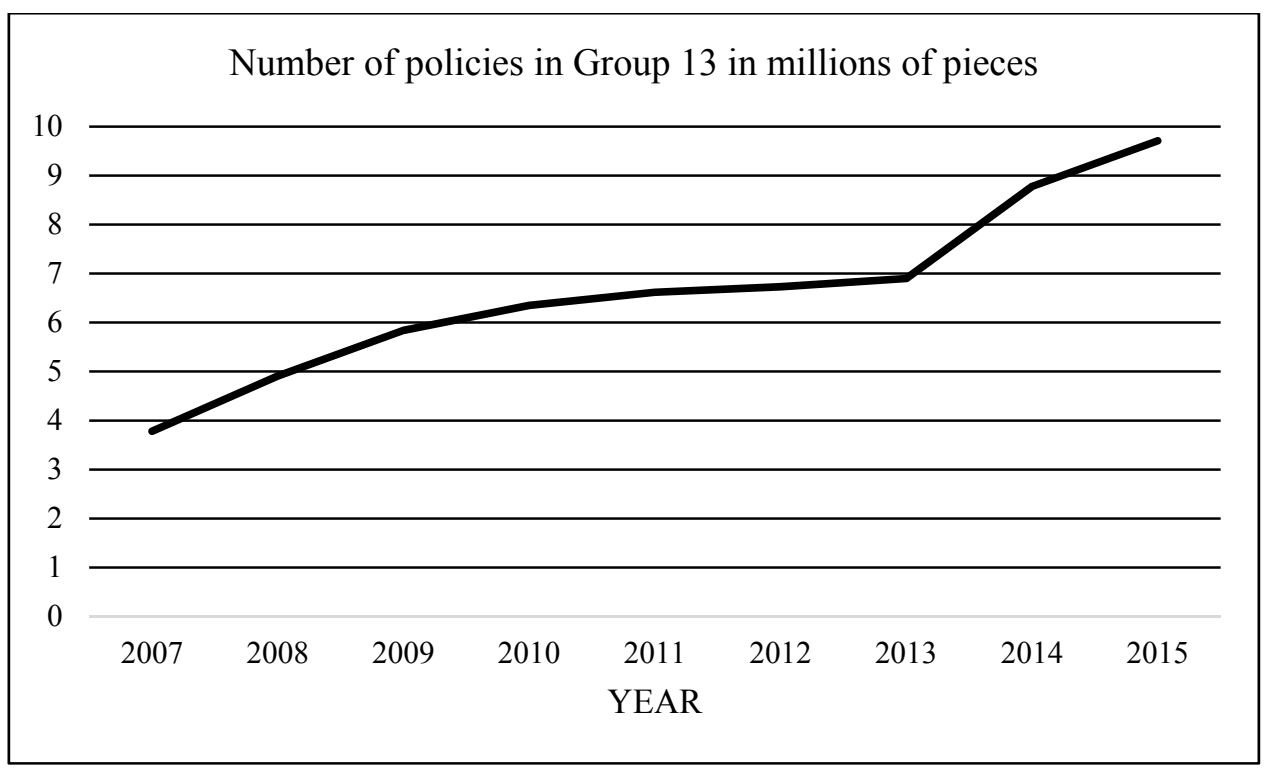

Figure 3. Number of general third party liability insurance policies (Group 13) in the years 2007-2015 (in millions of pieces)

(source: own elaboration on the basis of: State Insurance Office Reports, Annual Reports, 2014, Financial Supervision

Commission Annual Reports; Annual Reports 2016; Financial Supervision Commission Reports; Quarterly bulletin. Insurance Market 4/2015)

Fig. 3 shows a markedly higher readiness to make use of third party liability insurance in risk management in the period preceding the economic collapse and in the period of the post crisis recovery, which provides evidence for the crucial influence of the financial standing of companies and households on the demand on the third party liability insurance market.
Simultaneously, the substantial growth in the share of general third liability insurance in the number of the remaining nonlife insurance and material insurance contracts (in particular against the decline in the number of Section II policies) visible in Fig. 5 shows how strong the influence of noneconomic factors is on the demand side of the third party liability insurance market.

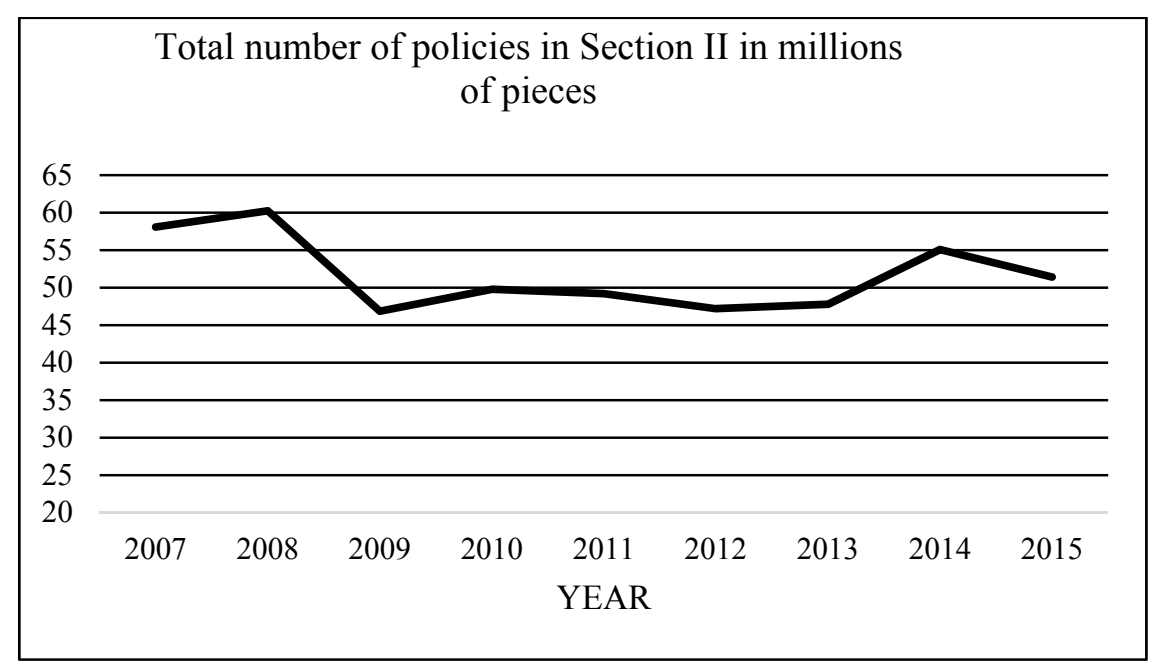

Figure 4. Total number of insurance contracts in Section II (groups 1-18) in the years 2001-2015 (source: own elaboration on the basis of: State Insurance Office Reports, Annual Reports, 2014, Financial Supervision Commission Annual Reports; Annual Reports 2016; Financial Supervision Commission Reports; Quarterly bulletin. Insurance Market 4/2015) 


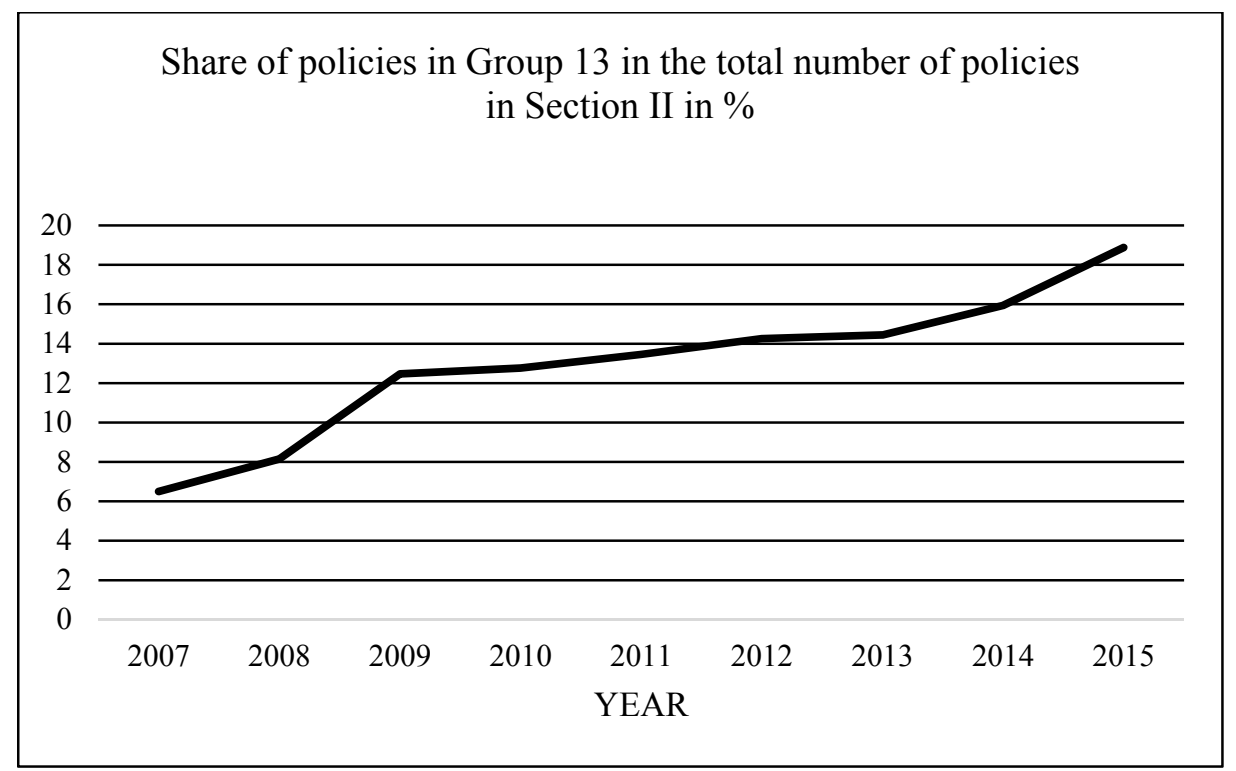

Figure 5. Share of general third liability insurance contracts (Group 13) in the total number of insurance contracts in Section II (Groups: 1-18) in the years 2007-2015

(source: own elaboration on the basis of: State Insurance Office Reports, Annual Reports 2014, Financial Supervision Commission Annual Reports; Annual Reports 2016; Financial Supervision Commission Reports; Quarterly bulletin. Insurance market 4/2015)

The presented trends in the third party civil liability insurance contracts in Poland witnessed recently are thus a consequence of the influence of a large number of a variety of factors, including the most commonly indicated financial standing of the demand market subjects and steady growth of the level of legal and insurance awareness among them. What is definitely worth mentioning is the multidimensional character of these determinants, resulting among others, from the construction of the third party liability insurance, which differs significantly from the construction of property insurance dominating among material insurance ${ }^{1}$. What can be observed concurrently with the process of the strengthening of the position of third party liability insurance in the insurance market and improvement in the approach to the process of risk management in organizations is an increased interest in this group of issues as a subject of scientific studies and analyses. Scientific activity in this area is fully justified first and foremost due to the high complexity of the legal nature of both third party liability ${ }^{2}$ and its in-

\footnotetext{
${ }^{1}$ Pursuant to Art. $821 \mathrm{cc}$ material insurance can refer to property or third party liability.

${ }^{2}$ Discussions concerning approach to the so-called pure economic loss in Poland against the relevant practice followed in other countries and growth in the number and value of claims in virtue of third party liability Kwiecień (2009, pp.63-76) can serve as
}

surance ${ }^{3}$, the diversity of insuring parties and beneficiaries as well as the dominant position of third party liability insurance among compulsory insurance in Poland.

\section{Nature and function of third party liability insurance as a basic determinant of the state and development of the third liability insurance market}

Discussions over the nature of third party liability insurance should be preceded by a definition of third party liability as an insurance object. In general, liability is the obligation to bear the consequences of one's own behavior or third parties' behavior foreseen by the law. Depending on the adopted criterion of its determination, we can distinguish criminal liability, disciplinary liability, constitutional liability, political liability, business liability, professional-

\footnotetext{
evidence of the complexity of the legal nature of third party liability and in consequence its insurance.

${ }^{3}$ Attention should here be drawn to the use as a temporary scope of insurance protection of the so-called triggers, the problem of which is frequently raised by specialists in the third party liability insurance law (e.g. Serwach, 2007a; 2007b).
} 


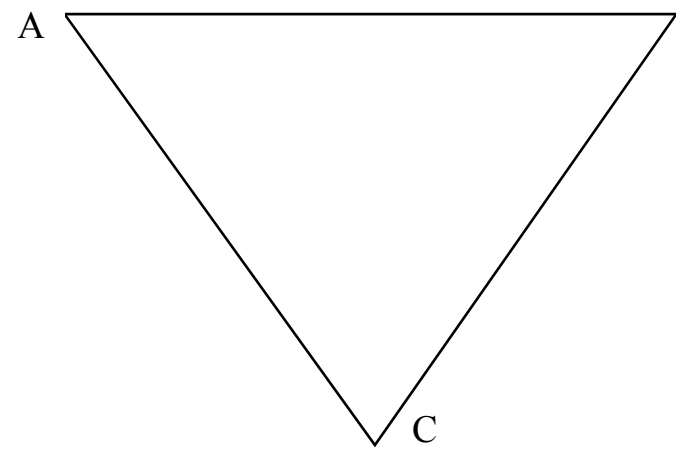

$\mathrm{B}$
A - policyholder
B - insurer
C - injured party
$\mathrm{AB}$ - third party liability contract
$\mathrm{AC}-$ ex delicto or ex contractu compensation relation
$\mathrm{BC}$ - action directa direct claim

Figure 6. Construction of third party liability insurance (source: Serwach, 2006, p.389)

liability and finally third party liability as a lawdetermined obligation to bear material consequences of one's own and third parties' behavior as well as of other events to which the law (civil code) links these consequences. It is worth remembering (particularly in the context of analyzing the importance of third liability insurance and identifying factors underpinning the development of the market for this insurance) that what is at stake is an unlimited financial liability of the debtor (limitations appear in the execution) and that the obligation to redress the damage applies to both the present and the future assets of the debtor.

Characterizing the nature of the third party liability insurance, we should distinguish two liability regimes: ex delicto (art. 415 and CC) and ex contractu (Art. 471 and CC), which constitute grounds for determining the source of the obligation toward the injured and in consequence of defining the object of insurance protection.

Third party liability insurance is most frequently defined in terms of its legal dimension. Pursuant to Art. 822. $\$ 1 \mathrm{CC}$, "By concluding a third party liability insurance contract an insurance institution undertakes to pay a compensation specified in the contract for damage to third parties in relation to whom liability is borne by the policyholder or a third party in favour of which the insurance contract was concluded." This approach shows clearly the specific character of links present in relations between the parties and subjects of the third party liability insurance relationship. First, like any other insurance contract, it indicates the presence of classic parties to the insurance relationship, that is, the insurer (insurance institution ${ }^{4}$ ) and the policyholder.

Generally speaking, being a party to the insurance relationship, the insurer has the basic obligation to pay a compensation and the policyholder has the basic obligation to pay the insurance premium (Art. $805 \S 1$ and $\S 2$ sect. 1 CC).

In turn, the basic insurance relationship subjects include, apart from (what is obvious) the insured (and thus a person indicated by name or otherwise, for the account of which the policyholder concluded the insurance contract), "the injured party in terms of third party liability insurance" ${ }^{, 5}$ as one of the entitled third parties (Art. $808 \mathrm{CC}$ ).

The specific character of third party liability insurance as compared with other nonlife insurance (in particular property insurance) finds its reflection in the very construction of this insurance (Fig. 6), which covers several separate but closely interlinked legal relationships (Nowakowski, 2004, p.112). The first of these relations arises from the third party liability insurance contract (whether voluntary or compulsory) concluded between the insured (policy-

\footnotetext{
${ }^{4}$ Though relevant literature raises doubts as to the adequacy of the term "insurance institution" to refer to a party to an insurance relationship and points to the relevance of using in this case the category "insurer," (e.g. Kowalewski, 2006, p.191), the two terms are often used interchangeably due to the fact that the term "insurance institution" appears in the civil code as well as in Art. 5.1. of the Law of May 22, 2003, on compulsory insurance, Insurance Guarantee Fund, and Polish Traffic Insurance Office.

${ }^{5}$ Pursuant to Art. $822 \S 4$ CC. and Art. 19 of the law on compulsory insurance, Insurance Guarantee Fund and Polish Traffic Insurers' Bureau - "if the perpetrator of the damage concluded a third party liability insurance contract - the injured party can claim compensation damages directly from its (perpetrator's) insurer" (Kowalewski, 2006, pp.192, 193).
} 
holder) [A] and thus a potential damage perpetrator and the insurer $[\mathrm{B}]$. The insurer undertakes to provide insurance protection consisting primarily (from the point of view of the client) in the payment to the injured party $[\mathrm{C}]$ of compensation (indemnity) in the case of the occurrence of the contract-covered event of which the policyholder (the insured) is the perpetrator. In turn, the policyholder undertakes to pay the insurer a premium.

- The second of the relations is a legal relation between the damage perpetrator [A] and the injured party $[\mathrm{C}]$. Damage due to a tort (in this case the perpetrator bears third party liability in tort) or damage being consequence of failure to comply with or inadequate compliance with a previ- ously undertaken obligation (in this case the perpetrator bears contractual third party liability) gives rise to an obligation to redress the damage within the scope not exceeding its material consequences.

- The third of the relations is the legal relation between the insurer $[\mathrm{B}]$ and the injured party $[\mathrm{C}]$, which arises as a consequence of the occurrence of the other two legal relations (between the insurer and the policyholder/the insured as well as the insured damage perpetrator and the injured party). The relation arises when the material consequences of the event give rise to an obligation on the part of the insured.

Table 4. Variants of the third party civil liability contract according to the subject of insurance protection (source: Mogilski, Serwach, 2011)

\begin{tabular}{|c|c|c|}
\hline Part & Subject of insurance protection & Third party liability insurance variant \\
\hline A & $\begin{array}{c}\text { The policyholder's third party liability } \\
\text { insurance exclusively }\end{array}$ & Insurance on one's own account \\
\hline B & $\begin{array}{c}\text { The insured's third party liability } \\
\text { insurance exclusively }\end{array}$ & Insurance on a third party's account \\
\hline C & $\begin{array}{c}\text { The policyholder's and the insured's third party } \\
\text { liability insurance }\end{array}$ & $\begin{array}{c}\text { "Total" insurance on one's own } \\
\text { and third party's account }\end{array}$ \\
\hline
\end{tabular}

A conclusion of a third party liability insurance contract by the damage perpetrator thus constitutes the assumption by the insurance institution of the material liability toward the injured party, which can lodge a claim directly with the perpetrator's insurer (action directa $)^{6}$. Legal literature treats the damage-

\footnotetext{
${ }^{6}$ What is interesting from the point of view of the development of the insurance market and in particular the relation between the insurer and the insured/policyholder is the gradual - since 2014 (pilot introduction by PZU SA) - introduction (at the initiative of PIU) of a possibility of damage claiming by traffic collisions victims holders of compulsory third party liability insurance under the BLS system (Direct Damage Liquidation). The BLS system developed in the Polish Insurance Chamber will be joined by the following insurers: Concordia Ubezpieczenia, Ergo Hestia, PZU, UNIQA, Warta (from April 1, 2015), Aviva, Liberty Ubezpieczenia (from July 1, 2015), and Gothaer (from October 15,2015$)$. Taken together, these insurers represent $68 \%$ of the third party liability insurance market measured with the premium levied. The Direct Damage Liquidation is a system creating a possibility to repair a car or to obtain damages from one's own third party liability insurer and not from the insurer of the damage perpetrator as it has been so far. BLS has been in operation on the European market for decades, among others in France, Belgium, Spain, and Italy.
}

related liability of the insurer as legal liability (Raczyński, 2010, p.43) or guarantee liability (which results from the application of the so-called absolute principle liability) (Czachórski, 1995, p.146-147). What should be drawn attention to is the amount of the guarantee amount in third party liability insurance representing the maximum level of the insurer's material liability toward the injured party. In the case of a damage the material value of which exceeds the scope of the financial liability of the insurance institution, the injured party can, in addition to the compensation paid by the insurer, claim damages from the perpetrator of the damage.

The subject of the insurance protection can cover only and solely the third party liability of the policyholder or/and holders as well as the third party liability of the insured. Depending on the subject of the

http://piu.org.pl/public/upload/ibrowser/BLS/Prezentacja_na_cz ym_polega_BLS.pdf [access: 05.06.2015]. 
insurance protection, we can distinguish three variants of the third party liability insurance contract.

Discussing the nature of the third party liability insurance, it is worthwhile to refer to its function as a factor constituting a sui generis lever of the development of the market for this kind of insurance. There is no doubt that better knowledge of its role can contribute to more common use of this risk management instrument by households, enterprises, nongovernment organizations, and other entities. Literature on the subject defines the function of economic insurance as "a form of the manifestation of their economic and social destination, namely, implementation of tasks imposed on it" (Sangowski, 1998, p.47). Apart from "classic" functions attributed to all types of insurance (protective function, compensatory function, preventive function, financial function $)^{7}$ third party liability insurance has particular tasks to perform because of its specificity:

- protection of the property of the policyholder (potential damage perpetrator) against loss resulting from the obligation to redress the damage caused,

- protection of the property of potential injured parties against loss resulting from a potential insolvency of the damage perpetrator (when the damage compensation obligations exceed the value of the damage perpetrator's assets).

An analysis of the third party liability insurance market development factors reveals that it is the first of the above functions that is of primary importance in shaping social attitudes toward risk management of civil liability with the help of insurance. The common awareness of the inevitability of bearing pecuniary consequences of damages inflicted on third parties (the extent of which cannot be foreseen $a$ priori) not only with the assets held today

\footnotetext{
7 The functions of insurance are perceived in a way slightly different from that presented by Sangowski and by Kowalewski (2006, p.33), who points to the "compensation of contingency losses" and "damage prevention (prevention of contingency losses)" as basic functions and expands this list with additional aims and tasks, i.e., (1) educational role; (2) ensuring a sense of security; (3) ensuring the continuity of economic goals; (4) guarantee of the principles of economic calculus as well as (5) others (stimulation of economic growth: credit - investments; export development; protection of the balance of payments; guarantee of the development of dangerous areas of activity: navigation, aviation, road traffic, nuclear power).
}

but also in the future seems to be the most effective incentive to seek insurance protection. The second of the functions listed can also be seen as a third party liability insurance market development factor but not as an individual incentive for potential damage perpetrators to provide themselves with insurance protection but as an argument raised to support the extension of the list of compulsory insurance (with third party liability insurance in the lead) which potentially increases the number of contracts concluded ${ }^{8}$.

\section{Risk-generating techniques and technolo- gies as determinants of the development of third party liability insurance market}

The third party liability insurance was developed most probably in the 18th century, though literature does not specify when exactly and when the scope of basic maritime insurance was expanded in Great Britain so as to cover insurance against collision liability. Initially, the solutions did not cover injury to person but their construction was based on a division of pecuniary liability for material damage between the insurer (in $75 \%$ of the cases, the risks were borne by associations of ship owners insuring their members reciprocally) and the ship owner who redressed $25 \%$ of the value of the damage for "educational reasons" (Raczyński, 2010, p.3).

At the same time, in France, solutions aimed at the protection of the financial interest of the injured party were developed within fire insurance for land ${ }^{9}$ as a result of the introduction of stricter regulations (based on the principle of risk) with respect to the liability of tenants towards owners of tenement houses in the case of damages due to fire.

The impulse to the emergence of a separate third party liability insurance as an independent category of insurance is most commonly believed to have been triggered by the dynamic development of the

\footnotetext{
${ }^{8}$ A similar view is presented by Orlicki who places the protection of socially important values among reasons underpinning the introduction and function of compulsory insurance (Orlicki 2011, p.196).

${ }^{9}$ An extended analysis of the origin and phases of the development of third party liability insurance in light of rich historical sources and evolution of the provisions of contract law can be found (Kowalewski 1981, pp.9-56).
} 
machine industry in the 19th century accompanied by threats to the health and life of workers. Sharing this perception of the origin of the third party liability insurance, Eugeniusz Kowalewski said: "the demand for insurance of this kind does not seem to be a simple function of the process of the objectification of the principles of liability but rather results from the intensification and proliferation of risks at the time of accelerated technical and organizational development" (Kowalewski, 2006, p.12). The industrial revolution resulted in an increase in the number of accidents at work, which generated a need to regulate the question of employers' pecuniary liability toward injured employees and their families and consequently led to increased interest in insurance protection. In the years 1838-1882, six countries (Prussia, Norway, Germany, Switzerland, Great Britain, and New Zealand) adopted laws providing for the employer's liability for damages caused by accidents at work. Although employers accepted these actions because the employer's liability resulted from the general principles of third party liability for damages inflicted on a person or to another person's property (Piotrowski, 1964, p.15). Yet, in practice, injured workers were not able to execute the payment of compensations from employers. As a result, many countries resorted to far-reaching forms of interventionism introducing compulsory insurance obligations (e.g. in Belgium in 1868 and in Belgium in 1868) (Księżopolski, 1999, p.27). This seems to confirm that the beginnings of social accident insurance date back to the first half of the 19th century while the second half of the 19th century witnessed the development of insurance related to accidents at work and work-related disability as an element of the system of social insurance (among others, in Germany in 1884 under insurance laws of Chancellor Otto von Bismarck). The construction of accident insurance refers as a rule to the nature of third party liability insurance (among others, the contribution is paid by the employer who is potentially liable to redress the damage, the value of the contribution being dependent on the level of risk of an accident at work or an occupational disease, the value of the damage/compensation being dependent on the size of the damage within the level of liability to be borne by the insurer and determined earlier on a lump sum basis), yet, paradoxically, though the introduction of this social insurance contributed to raising the awareness of risk among employers, it did not contribute to development of third party liability insurance. Employers were made to believe that accession to social insurance systems releases them from liability for damages and the obligation to directly redress the damage. It was only with the introduction in many countries in the second half of the 20th century (in Poland as late as in 1990) (Gasińska, 2003, pp.209-219) of legislation enabling the injured employees or their families to lodge supplementary claims (pursuant to the principle of subsidiarity, by way of a civil action) with employers and drew their attention to the need to ensure additional protection in the form of commercial civil liability insurance. The above example confirms the relevance of opinions pointing to strong social connotations of the insurance method to be found in scientific discourse (Szumlicz, 2005a, pp.27-41). We can include a substitutive function of accident social insurance in relation to commercial (economic) insurance, which results from the fact that with the introduction of the risk of accidents at work and occupational diseases to the system of (compulsory, common, state-organized) social insurance practically eliminated the motivation of the employers to conclude voluntary third party liability insurance on the insurance market. In turn, the introduction of regulations enabling employees to place "supplementary" claims through civil action ${ }^{10}$ gradually encouraged employers to conclude commercial third party liability insurance contracts ensuring full compensation of damages. This approach allows to perceive commercial third party liability insurance as a supplement to social insurance (Szumlicz, 2005b, p.197).

Another factor underpinning the development of third party liability insurance was technical progress in transport and the resultant threats. For instance, in France, the first third party liability insurance for owners of horses and carriages appeared in 1825 (Raczyński, 2010, p.5) and in 1895 the Automedon insurance company added to their offer insurance against consequences of accidents

\footnotetext{
${ }^{10}$ The civil liability of the employer for damages to the employee, which arose in result of an accident at work or occupational disease is discussed extensively (Jachimowicz, 2013, pp.192217).
} 
and protection of the pecuniary interests of perpetrators in horse transport. The appearance of cars with combustion engines and the development of car transport at the turn of the $19^{\text {th }}$ and the $20^{\text {th }}$ century provided another impulse for the development of motor third party liability insurance, which gradually came to be included in the list of compulsory insurances (e.g., in Norway in 1912, in Switzerland in 1914, in Denmark in 1918, in England in 1930, in Poland in 1962) (Górski, 1995, pp.89-91).

It is emphasized that technical progress means not only positive changes in, for instance, the structure of own production costs, structure of employment, structure of employees qualifications, and organization of production and work (Encyklopedia Zarzadzania, 2015) but also constitutes a source of numerous threats (to life, health and property) resulting from the emergence of an enormous number of ever more complex, often difficult-to-operate equipment and mechanisms as well as from the commonness of their usage which leads to a considerable growth of the so-called damage potential (Kowalewski, 1981, pp.12-13). This term, closely linked to third party liability insurance, refers most generally to the "potential scope of damages which a given subject can inflict to third parties in the event of the so called "black scenario," that is, the most pessimistic development of circumstances dependent or independent of the subject" (Sukiennik, 2003). Thus, the more mass the product or the service, the higher the risk of the occurrence of damages the redressing of which is likely to exceed the financial (pecuniary) abilities of the manufacturer of the product or the provider of the service ${ }^{11}$. A high level of the "damage potential" generates, on the one hand, strong motivation to make use of insurance protection and simultaneously induces decision makers to introduce compulsory third party liability insurances due to social considerations. What is worth mentioning here is the existence of a kind of a feedback mechanism, namely, the influence of the third party liability insurance market on technical innovation laden with a high level of risk? The possibility of making use of insurance protection increases the

\footnotetext{
${ }^{11}$ Naturally, apart from the scale (mass character) one should also take into account the potential value of an individual damage and the likelihood of its emergence.
}

chances of the application of technologies of this kind in practice and consequently has a positive impact on the development of research and inventiveness.

\section{Socioeconomic determinants of the devel- opment of third party liability insurance}

The discussion of the stages and determinants of the historical development of third party liability insurance market cannot fail to mention the role played by socioeconomic factors (which can both stimulate and hamper its growth) and, among them, the importance of the level of legal and insurance awareness of potential damage perpetrators and injured parties, the financial standing of households, and the financial standing of economic entities.

The psychosocial factors hampering the development of the market include the disrepute once surrounding third party liability insurance in many publications concerning insurance protection of perpetrators of damage ${ }^{12}$. Arguments were raised that the awareness of this protection does not favor prudence and development of attitudes and behaviors of preventive character. On the contrary, it encourages the policyholder to sort of play with risk (and thus with the insurer), which involves the phenomenon of emotional (spiritual) hazard and actually constitutes a source of dangerous irresponsibility ${ }^{13}$. Fortunately, ever more rarely, is third party liability insurance treated as a pass to impunity, the more so since insurance clauses overtly point not only to the requirement of caution in behavior but also deprive the insured of the right to the compensation of the damage by the insurance company in the case the damage was a consequence of deliberate misconduct, stark negligence, inebriation of the perpetrator, failure to take actions reducing the consequences of the event, etc. Seeking a lever of the development of third party insurance in factors of social character, we should pay attention to the level of legal and in-

\footnotetext{
${ }^{12}$ Against this background it is interesting to read the opinion of Kowalewski that only the differentiation of the criminal ("punishing" justice) and civil aspect ("compensatory" justice) of the tort removed the odium from third party liability insurance (Kowalewski, 1981, p.13).

${ }^{13}$ This view was held by G. Ripert (after:) Stelmachowski (1984, p.316).
} 
surance awareness on the demand side of the insurance market. Changes to social awareness result from a process, which is product of different forms of education both formal and nonformal and, obviously, individual experience. For example, the dynamic growth of third party liability insurance in the United States in the second half of the $20^{\text {th }}$ century was caused, among others, by very high damages, which, in light of American law practice, do not play solely a compensatory function but also, frequently, a penal function. The possibility of the application of the class action suit principle, that is of a single entity bringing an action in a situation when the latter represents many potentially injured parties (mass products, procedures applied in global networks, etc.), law offices specialized in collective disputes concerning claims from civil action, publicizing of cases in the which the injured natural person or a small firm are assumed to be the weaker, and thus special treatment requiring subject, constitute basic factors generating the development of the third party liability insurance market. What is worth giving attention to in the above context is the danger of the appearance of a pathology of a kind resulting from behavioral reasons - the emergence in the United States of a litigious society and consequently actions restraining the scope and level of claims (e.g., voluntary payments of substantial amounts made by cigarette manufacturers toward federal prevention funds in order to avoid prolonged court trials and exorbitant claims).

The growth of the legal awareness as regards the nature and function, in particular the compensatory function, of third party liability as well as insurance awareness of benefits for the injured resulting from insurance protection causes growth of demand for third party liability insurance as it comes to be present in business negotiations in the form of a peculiar compulsory obligation of contractual character (even where the obligation is not foreseen by law).

On the other hand, like in the case of many other types of insurance, macro- and micro-economic factors as well as the cyclical character of market economy come into play (poorer economic performance by enterprises and lower incomes of the population generate smaller interest in insurance protection while recovery and prosperity increase the demand for insurance). In particular, the deterioration of the financial standing of economic entities and households can significantly lower their interest in voluntary third party liability insurance. In conditions of a lower level of insurance awareness with simultaneous poor knowledge of the nature of the legal liability for damage (and it is this situation that can be seen in the majority of postcommunist societies), what is observed is a trend toward securing the insurance protection of one's own property rather than transferring the risk of bearing third party liability to the insurer. This attitude of subjects responsible for risk management usually stems from the belief that what should primarily be protected is one's own state of possession, the hard to estimate material costs of redressing the damage being given less attention. Another circumstance to be pointed to speaking about economic determinants is the significance of transformations in the ownership and organizational-legal structure and against their background the ever more common separation of corporate management and corporate governance functions. A manager is liable toward the company itself, shareholders, partners, other board members, business partners, State Treasury, supervisory bodies (in Poland - Commission for Financial Supervision), employees, and third parties. The scope of liability is thus very wide and managers are liable not only with their present but also future assets for faulty decisions and negligence, which generate losses to the firm as well as for the consequences of their failure to perform their duties as the employer (Sikorski, 2015). The growth of requirements toward managers and the ever larger awareness of the right to pursue claims, the ease of exchanging information and establishing relations between the injured parties on the net as well as the ever more common practice of taking class actions have created crucial grounds for the development of managerial third liability insurance. The first managerial third-party liability insurance policies appeared on the insurance market in the 1930s after the crash on the New York Stock Exchange. European insurance markets came to offer this form of insurance in the 1970s. A particular growth of demand for these policies had place in the aftermath of the latest economic crisis of the first decade of the $21^{\text {st }}$ century. The enormous losses resulting from not only mismanagement but primarily 
financial affairs (e.g. Enron, World.com, Tyco, Adelphia, etc.), along with the collapse of global economy as a consequence of irresponsible management and inadequate supervision, generated an enormous wave of actions and incredibly high claims the scale of which made guarantee amounts skyrocket. For instance, in 2011, the average guarantee amount for which D\&O insurance was signed reached $\$ 126.8$ million. At present almost $100 \%$ of public companies in Western Europe have D\&O policies. D\&O policies have been present on the Polish market for over 23 years and also, as a result of the postcrisis erosion of trust in managers, they are flourishing. The guarantee amounts also keep growing, for instance, one Polish company got insured against their erroneous decisions under D\&O policy at a billion Polish zlotys (source: Gazeta Ubezpieczeniowa, Rynek Ubezpieczeń). D\&O insurance (liability insurance of board members and other executive staff), POSI (Initial Public Offering Insurance), E\&O insurance (errors \& omissions insurance), EPLI (employment-practices-liability-insurance of managers) represent the scope of effective and ever more popular insurance protection as a method of risk management applied by managers.

Looking for phenomena heralding the development of the third party liability insurance market among determinants linked to the transformation of the economy, one can see them in the growth of oneperson nonagricultural economic entities as well as economic entities arising in consequence of the outsourcing of functions, which used to form part of the core activity of many large firms. The professional and economic activity thus performed generates the need felt by an ever larger number of enterprises for insurance protection as regards pecuniary liability for default on an obligation related to a dangerous product, for damages linked to ownership or the use of forces of nature.

\section{The importance of legal regulations for the development of third party liability insurance market}

What played a crucial role among the determinants of the development of third party liability insurance market were legal regulations, including regulations objectifying third party liability as a category of private law separate from penal law (Kowalewski, 1981, p.13) and in consequence emphasizing its economic dimension (the obligation to redress the damage by its perpetrator). Among the three functions of third party liability specified in literature (System prawa cywilnego, 1981, pp.208-211; Czachórski 1995, pp.74-75) (compensatory, repressive, preventive-educational), it is the compensatory function that determines the shape, scope, and practice of third party liability insurance.

What is worthwhile to draw attention to in this place are regulations making the scope and principles of third party liability stricter, which must naturally affect the perception of insurance as not solely an instrument guarding the financial interest of the potential tortfeasor but in the case of the application of the principle of risk, also the way of passing over to the insurance institution of the burden of proving the existence of exonerating circumstances (as a condition of relieving oneself of the obligation to redress the damage). Such was, for instance, the impact on the development of the offer and market of the insurance of obligations of the introduction to the Civil Code (Articles $449^{1}$ to $449^{11}$ ), following the law of March 2, 2000, on the protection of certain consumers' rights and liability for a dangerous product (Journal of Laws of 2012, Item 1225), of legal regulations specifying broadly the circle of entities liable for damage due to a dangerous product. It was not only manufacturers (and thus entities the activity of which involves manufacture of potentially dangerous products) but also manufacturers of materials, raw materials and components, nominal producers (placing their name or trade mark on the product or acting as a producer), importers (subjects putting products on the market), and even sellers (i.e., persons selling products where the producer cannot be determined) that came to be interested in third party liability insurance. Liability for damage inflicted by the insured product covers equally damage to property and damage to person and changes to legal regulations merely made the liability regime stricter by introducing the principle of risk - very strict indeed from the point of view of potential tortfeasors. The fact that it is on the potential tortfeasor, if the latter wants to prove free 
of liability, that the obligation to present one of the exonerating circumstances (and thus prove that it was not the tortfeasor who admitted the product to trading or that the product was stolen or lost or that the dangerous properties of the product appeared only after its admission to trading and did not result from a reason present in the product previously, or that the state of science and technique did not allow to predict the dangerous properties of the product) rests, can effectively encourage the potential tortfeasor to conclude a third party liability contract (thanks to which the tortfeasor can also count on the insurer's support in gathering and presenting evidence material as regards the appearance of the circumstances of the event, which is usually a very difficult and complicated task where the principle of risk applies.

In light of peculiar "inflation of the compulsoriness of insurance" witnessed in Poland, a phenomenon long contested and referred to in literature as a "legislative defeat" and even "legislative pathology" (Kowalewski, Ziemniak 2015, p.1), controversies may arise over the perception of the legal provisions related to obligation to conclude an insurance contract as one of factors responsible for the development of the third party liability insurance market. Though it is hard not to share the opinions of lawyers, economists, social and economic analysts that an excessive extension of the list of compulsory insurances ${ }^{14}$ constitutes an assault of sorts at the freedom of concluding contracts in a market economy, it is also hard not to notice that this phenomenon generates demand for third party liability insurance ${ }^{15}$. The basic sources of compulsory insurance law in Poland, constituting a separate section of economic insurance law, include, apart from the law of May 22, 2003 on compulsory insurance, the Insurance Guarantee Fund and the Polish Traffic Insurers' Bu-

\footnotetext{
14 Although traditionally France was given as an ex ample of a state breaking records in the imposition of compulsory insurance obligations, the report recently published by the PIU indicates that Poland can also find itself in the record list with 215 compulsory and mandatory types of insurance, Internetowy Tygodnik Ubezpieczeniowy 26/2015,

https://www.google.pl/?gfe_rd=cr\&ei=ZJgMV5uSEqv8weJ37r4 DA\&gws_rd=ssl\#q=Internetowy+Tygodnik+Ubezpieczeniowy+ 26\%2F2015 [access: 03.07.2015].

${ }^{15}$ For example, M. Orlicki perceives compulsory insurance as a factor in the development of the third party liability insurance market (Orlicki 2011, p.217).
}

reau (Journal of Laws, No. 124, Item 1152 with amendments), and the Civil Code:

- laws (or international agreements) also referred to as "peri-insurance" laws (Kowalewski, 2006, p.87-88) which, pursuant to Art. 4 pt. 4 of the law on compulsory insurance contain provisions introducing the obligation to conclude an insurance contract on entities the activity of which is by nature of particularly dangerous character (e.g., nuclear energy generation), can threaten the health and life of people (e.g., medicine, clinical trials, hunting, mass events, etc.), can involve rendering specialist services (e.g., detective investigations, financial, legal, architectural, etc.) (Mogilski, 2006, pp.272-275). The number of these "periinsurance" laws tends to become longer and longer.

- executive acts to the laws introducing compulsory insurance, namely, decrees of the Minister of Finance on compulsory insurance (specified in a law or in an international agreement) specifying, in their majority, the scope of protection and minimum guarantee amounts.

One of the examples of the construction of legal regulations concerning compulsory insurance sensu stricto is the law of September 18, 2001 on the electronic signature (Law of September 18, 2001, on the electronic signature, Journal of Laws 2001, No. 130 Item 1450), Art. 10 Sect. 1 pt. 4, which stipulates that a qualified subject providing certification services issuing qualified certificates is obligated to conclude a third party liability insurance contract for damage to recipients of certification services as well as the enforcement act to the law - decree of the Minister of Finance of December 16, 2003 on compulsory third party liability insurance of the certification-providing subject ${ }^{16}$. Apart from provisions concerning the scope of the obligations of the subject and the deadline for concluding the insurance contract, the decree specifies the minimum guarantee amount of the third party liability insurance with respect to one event the consequences of which are covered by the said contract is the Polish zloty

\footnotetext{
${ }^{16}$ Decree of the Minister of Finance of December 16, 2003 on compulsory third party liability insurance of a qualified subject providing certification services (Journal of Laws 2003, No. 229 Item 2282).
} 
equivalent of $€ 250000$, but not exceeding $€ 1000$ 000 for all events.

The appearance in relevant decrees of the Minister of Finance of a minimum guarantee amount as the upper level of the financial liability of insurers for damages which may have been caused by the policyholder has also an indirect influence on the third party liability insurance market. Economic entities do not always limit themselves to the insurance protection which they are guaranteed under compulsory agreements (mandatory or resulting from international agreements). In particular, where the size of the damage is likely to exceed the guarantee amount because of the specificity and international scope of activity, the role of voluntary insurance, as supplementary to compulsory insurance, increases which contributes to growth of demand on the third party liability market.

The role of compulsory insurance sensu stricto as a lever of the development of the third party liability insurance market reinforces the imposition on insurance institutions of the obligation to accept offers pursuant to Art. 5 pt. 2 of the law on compulsory insurance (Kowalewski, Ziemniak, 2015, p.7).

As specific provisions of certain laws (there are seven of them in the current list of compulsory insurance sensu stricto) introduce a possibility of choosing insurance as one of the options (e.g., next to bank or insurance guarantees or deposits of funds in a special account), not all entities may make use of third party liability insurance as an instrument of managing the risk of insolvency. Where third party liability insurance is of conditional rather than absolute character pursuant to the provisions of the law, ${ }^{17}$ it is referred to in literature as "compulsory variantive insurance" (Kowalewski, Ziemniak, 2015, p.7). A legal provision of this kind may thus reduce

\footnotetext{
17 This situation refers, for instance, to the third party liability of a nurse or a midwife being citizen of a EU member state, practising the profession of a nurse or midwife, temporarily or occasionally in the territory of Poland (Art. 24 law of 15 July 2011 on the professions of a nurse and midwife, uniform text of 2014, Item 1435 with amendments) and also third party liability insurance of an entrepreneur conducting economic activity in the area of organizing tourist events or mediating, on clients' request, in concluding contracts on the provision of tourist services, in the case of their insolvency (Art. 5 of the law of August 29, 1997, on tourist services, uniform text of 2014, Item 196 with amendments)
}

the readiness to make use of compulsory insurance as an instrument of risk management in favor of other instruments specified in the law and in consequence decrease the contribution of compulsory third party liability insurance to the growth of the market.

By the way, it is worthwhile to mention other types of third party liability insurance, which belong to the set of the so-called compulsory insurance sensu largo linked to the broadly understood insurance compulsion as a legal obligation or to a (more or less directly) imposed duty to have insurance protection, which do not satisfy the requirements of Art. 4 of the law on compulsory insurance, Insurance Guarantee Fund, and Polish Traffic Insurers' Bureau, and their undeniable contribution to the growth of demand for insurance protection (Kowalewski, Ziemniak, 2015, p.8).

\section{Conclusion}

The steady growth of the Polish third party liability insurance market, measured in terms of the number of contracts concluded, collection of insurance contributions as well as growth of the share of third party liability insurance in Section II insurance (other personal insurance and financial insurance) has been observed in Poland for some time now. Simultaneously, insurers tend to expand their offers with modern products protecting the financial interests of both potential injured parties and potential tortfeasors in events generating property liability, products responding to the needs of the domestic market, frequently already tested on other insurance markets. The above tendency allows to express a view that while the third party liability insurance market in Poland in statu nascendi has been developing over the past 25 years, which is understandable in the face of stormy changes it has been undergoing due to systemic transformation, it also has good prospects for further development. It is therefore worthwhile to follow factors that have been underpinning the growth of the third party liability insurance market as their observation is not merely of historical value but can be used to design effective instruments which will support further development of this market in the future. The actions of insurance 
institutions, insurance market institutions, and the activity of other entities affecting its shape and growth should take into account the multidimensional character of the third party liability insurance market which is dominated by:

- determinants resulting from relations between parties and subjects to the third party liability insurance relation against the complex nature and specific character of the third party liability function,

- determinants linked to the dynamic growth of the so called risk-generating techniques and technologies leading to increase in the occurrence of the so-called damage potential threatening participants in the production process (service-rendering process) as well as product users and service recipients,

- determinants of socioeconomic character, in particular the level of legal and insurance awareness of potential tortfeasors and injured parties as well as the financial standing of households and economic entities,

- determinants related to legal regulations, in particular, the leading role of regulations separating the compensatory function of third party liability from its penal function in shaping the scope and level of insurance protection. What was emphasized, in addition, was the importance of regulations making the scope and principles of third party liability stricter in certain areas of economic turnover as well as regulations introducing the insurance obligation.

\section{$7 \quad$ References}

[1] Czachórski, W., 1995. Zobowiqzania. Zarys wyktadu. Warszawa: Wydawnictwa Prawnicze PWN.

[2] Decree of the Minister of Finance of 16 December 2003 on compulsory third-party liability insurance of a qualified subject rendering certification services, 2003. Journal of Laws, No. 229, Item 2282.

[3] Encyklopedia Zarzadzania, 2015. [online] Available at: http://mfiles.pl/pl/index.php/Post $\%$ C4\%99p_techniczny
[4] Financial Supervision Commission Annual Reports, 2014. [online] Available at:

https://www.knf.gov.pl/opracowania/rynek_ubez pieczen/Dane_o_rynku/Dane_roczne/archiwum .html [Accessed: 30. 09.2015].

[5] Financial Supervision Commission. Annual Reports. 2015. [online] Available at: https://www.knf.gov.pl/opracowania/rynek_ubez pieczen/Dane_o_rynku/Dane_kwartalne/dane_ kw.html [Accessed: 11.04.2016].

[6] Gasińska, M., 2003. Ubezpieczenie jako metoda zarządzania przez pracodawcę ryzykiem wypadku przy pracy. In: Ubezpieczenia w Polskim obszarze rynku europejskiego. Wyzwania i oczekiwania, Bydgoszcz: Branta.

[7] Gasińska, M., 2010. Zarządzanie ryzykiem odszkodowawczym menedżerów. In: Monkiewicz J., Gąsiorkiewicz L. (eds.). Zarządzanie ryzykiem organizacji. Warszawa: C.H. Beck.

[8] Gazeta Ubezpieczeniowa, Rynek Ubezpieczeń, [online] Available at: http://www.gu.com.pl/ index.php?option=com_content\&view=article\&id $=46850$ :rynek-ubezpie cze-dao-o-rekordowejwartoci\&catid=107:rynek -ubezpiecze\&Itemid =106, [Accessed: 05.06. 2015]

[9] Górski, W., 1995. Ubezpieczenia w transporcie i komunikacji. Zielona Góra: Agencja Rozwoju Regionalnego w Zielonej Górze.

[10] Internetowy Tygodnik Ubezpieczeniowy (2015), No 26, [online] Available at: https://www. google.pl/?gfe_rd=cr\&ei $=$ ZJgMV5uSE-v8weJ37r4 DA\&gws_rd=ssl\#q=Internetowy+Tygodnik $+\mathrm{Ub}$ ezpieczeniowy $+26 \% 2 \mathrm{~F}$.

[11] Jachimowicz, M., 2013. Wypadki przy pracy i choroby zawodowe. Świadczenia ubezpieczeniowe i cywilne. Warszawa: Difin.

[12] Kowalewski, E., 1981. Ubezpieczenie odpowiedzialności cywilnej. Funkcje i przemiany. Toruń: Uniwersytet Mikołaja Kopernika.

[13] Kowalewski, E., 2006. Prawo ubezpieczeń gospodarczych. Wyd. III, Bydgoszcz: Branta.

[14] Kowalewski, E., Ziemiak, M., 2015. Stan prawny ubezpieczeń obowiazkowych $w$ Polsce. [online] Available at: http://www.piu.org.pl/ wydania-specjalne [Accessed: 05.10.2015].

[15] Księżopolski, M., 1999. Polityka Społeczna. Wybrane problemy porównań międzynarodowych. Katowice: BPS. 
[16] Kwiecień, I., 2009. Czyste straty finansowe ryzyko odpowiedzialności i zakres ochrony w ubezpieczeniach OC podmiotów gospodarczych. Zarys problematyki. Wiadomości Ubezpieczeniowe, No 4.

[17] Kwiecień, I., 2015. Kultura roszczeniowa $-d y$ namika zjawiska $w$ kontekście odpowiedzialności cywilnej i ubezpieczeń. [online] Available at: http://rf.gov.pl/files/67_5211_Rozprawy_Ube zpieczeniowe.pdf.

[18] Law of 15 July 2011 on the professions of a nurse and a midwife, Journal of Laws 2014, Item 1435

[19] Law of 18 September 2001 on the electronic signature. Journal of Laws 2001, No. 130, Item 1450.

[20] Law of 22 May 2003 on compulsory insurance, insurance guarantee fund and Polish traffic insurers bureau. Journal of Laws, 2003, No. 124, Item 1152.

[21] Law of 29 August 1997 on tourist services (uniform text, Journal of Laws, 2014, Item 196 with amendments).

[22] Mogilski, W.W., 2006. Ubezpieczenia obowiązkowe. In: Kowalewski E., Prawo ubezpieczeń gospodarczych. Wyd. III, Bydgoszcz: Branta.

[23] Mogilski, W.W., Serwach M., 2011. Ochrona ubezpieczeniowa wzajemnych roszczeń ubezpieczonych w umowie ubezpieczenia OC. Wiadomości Ubezpieczeniowe, No 4. [online] Available at: http://httpwww.polisynazdrowie.pl /public/upload/ibrowser/WU/WU4_2011/mogils ki-serwach.pdf.

[24] Nowakowski, L., 2004. Ubezpieczenia odpowiedzialności cywilnej. Warszawa: Poltext.

[25] Orlicki, M., 2011. Ubezpieczenia obowiqzkowe. Warszawa: Wolters Kluwer.

[26] Piotrowski, J., 1964. Zabezpieczenie spoleczne. Warszawa: SGPiS.

[27] PIU, 2015. Bezpośrednia Likwidacja Szkód, [online] Available at: http://piu.org.pl/public/ upload/ibrowser/BLS/Prezentacja_na_czym_pol ega_BLS.pdf [Accessed 05.06. 2015].

[28] Polish Insurance Office, 2014. Annual Report. [online] Available at: https://www.piu.org.pl /public/upload/ibrowser/Raport\%20Roczny\%20
2014/Raport\%20Roczny\%20PIU\%202014.pdf [Accessed: 30.09.2015].

[29] Raczyński, A., 2010. Sytuacja prawna poszkodowanego $w$ ubezpieczeniu odpowiedzialności cywilnej. Warszawa: C.H. Beck.

[30] Radwański, Z. (red.), 1981. System prawa cywilnego. Prawo zobowiqzań - część ogólna. Vol. III, Wrocław: PAN.

[31] Sangowski, T. (red.), 1998. Vademecum ubezpieczeń gospodarczych (pośrednika ubezpieczeniowego). Poznań: Saga Printing.

[32] Serwach, M., 2006. Odpowiedzialność cywilna i ubezpieczenie OC. In: Kowalewski E. Prawo ubezpieczeń gospodarczych. Bydgoszcz-Toruń: Branta.

[33] Serwach, M., 2007a. Swoboda wyboru triggers oraz wynikające $\mathrm{z}$ niej zagrożenia dla rynku ubezpieczeniowego. Prawo Asekuracyjne, No 2.

[34] Serwach, M., 2007b. Triggery - wolność kontraktowa. Miesięcznik Ubezpieczeniowy, November.

[35] Sikorski, S., 2015. Odpowiedzialność cywilna członków organów spótek kapitałowych - ubezpieczenie Directors and Officers $(D \& O)$. [online] Available at: http://www.ksiegarnia. beck.pl/pdf/Odpowiedzialnosc_kadry_zarzadzaj acej_fragment.pdf.

[36] State Insurance Office Reports. [online] Available at: https://www.piu.org.pl/analizy-i-raporty [Accessed: 30.09.2015].

[37] Stelmachowski, A., 1984. Wstęp do teorii prawa cywilnego. Warszawa: PWN.

[38] Sukiennik, P., 2003. Potencjat szkodzenia. Dziennik Ubezpieczeniowy, No 846. [online] Available at: http://dziennikubezpieczeniowy. pl/2003/10/21/Potencjal_szkodzenia/artykul/136 61.

[39] Szumlicz, T., 2005a. Metoda ubezpieczenia interpretacja społeczna. In: Szumlicz T. (red.). Społeczne aspekty ubezpieczenia. Warszawa: SGH.

[40] Szumlicz, T., 2005b. Przyczynek do teorii ubezpieczenia spolecznego. In: T. Szumlicz, red. Społeczne aspekty ubezpieczenia. Warszawa: SGH. 